\title{
Pengaruh Sistem Olah Tanah Jangka Panjang, Pemupukan N dan Residu N terhadap Serapan Hara Mikro dan Produksi Tanaman Jagung (Zea mays $\mathrm{L}$ ) Setelah Pengolahan Lahan Kembali
}

\section{The Effect of Long-Term Soil Tillage System, N Fertilization and N Residue on Micro Nutrient Uptake and Production of Corn (Zea mays L) after Re-Tillage}

\author{
Meza Yupitasari $^{1 \star}$, Muhajir Utomo $^{2}$, Agus Karyanto $^{3}$, Abdul Kadir Salam $^{2}$ \\ ${ }^{1} J u r u s a n$ Magister Agronomi, Fakultas Pertanian, Universitas Lampung \\ 2 Jurusan IImu Tanah, Fakultas Pertanian, Universitas Lampung \\ ${ }^{3} J u r u s a n$ Agroteknologi, Fakultas Pertanian, Universitas Lampung \\ `Email: mezayupitasari30@gmail.com,mutomo2011@gmail.com
}

\author{
Disubmit: 11 September 2019 Direvisi: 16 Desember 2019 Diterima: 16 Januari 2020
}

\begin{abstract}
Abstrak: Tujuan dari penelitian ini yaitu untuk melihat bagaimana pengaruh TOT jangka panjang yang diolah kembali dan residu pemupukan $\mathrm{N}$ terhadap produksi dan serapan hara tanaman jagung. Penelitian ini merupakan bagian dari penelitian jangka panjang tahun ke-30 yang dilaksanakan pada bulan Februari hingga Juni 2017. Penelitian ini dirancang dengan rancangan split-split plot, tiga faktor dengan empat ulangan. Faktor pertama adalah sistem TOT dan olah tanah minimum (OTM) yang telah diolah, dan olah tanah intensif (OTI). Faktor ke dua pemupukan nitrogen dengan dosis $0 \mathrm{~kg} \mathrm{~N} \mathrm{ha}^{-1}$ (NO), dan $200 \mathrm{~kg} \mathrm{~N} \mathrm{ha}^{-1}$ (N1). Faktor ke tiga residu nitrogen,yaitu residu $0 \mathrm{~kg} \mathrm{~N} \mathrm{ha}^{-1}$ (NOr); dan residu $200 \mathrm{~kg} \mathrm{~N} \mathrm{ha}^{-1}$ (N1r). Data dianalisis ragam menggunakan program statistik 8 dan uji lanjutan dengan menggunakan uji BNJ pada taraf $5 \%$. Hasil penelitian tahun ke-30 menunjukkan bahwa setelah lahan TOT jangka panjang dilakukan pengolahan kembali dapat meningkatakan serapan hara mikro ( $\mathrm{Fe}, \mathrm{Mn}, \mathrm{Zn}, \mathrm{Cu}$ dan $\mathrm{B}$ ) dan produksi TOT $\left(5,99 \mathrm{t} \mathrm{ha}^{-1}\right)$ lebih tinggi bila dibandingkan dengan OTM $\left(5,23 \mathrm{tha}^{-1}\right)$ dan OTI $\left(4,43 \mathrm{t} \mathrm{ha}^{-1}\right)$. Pemupukan 200 $\mathrm{kg} \mathrm{N} \mathrm{ha}^{-1}$ menghasilkan serapan hara mikro (Fe, Mn, Zn, Cu dan B) dan perlakuan $200 \mathrm{~kg} \mathrm{~N} \mathrm{ha}^{-1}(5,90 \mathrm{tha}$ $\left.{ }^{-1}\right)$ memiliki produksi yang tinggi bila dibandingkan dengan $0 \mathrm{~kg} \mathrm{~N}^{-1}\left(4,53 \mathrm{t} \mathrm{ha}^{-1}\right)$. Residu N berpengaruh nyata terhadap serapan hara $\mathrm{Mn}$ dan produksi tertinggi pada residu $200 \mathrm{~kg} \mathrm{~N}^{-1}\left(5,59 \mathrm{t} \mathrm{ha}^{-1}\right)$. Hal ini berkaitan erat dengan pengolahan kembali pada lahan TOT memacu mineralisasi bahan organik tanah dan melepasakan hara yang dibutuhkan dan tersedia bagi tanaman. Selain itu pada lahan TOT menggunakan prinsip pengembalian sisa tanaman sebagai mulsa, sehingga akan meningkatkan kualitas tanah dan meningkatkan kelembaban, ketersedian air tanah, perbaikan agregasi dan prositas, sehingga akan meningkatkan serapa hara tanaman dalam membantu pertumbuhan dan perkembangan tanaman yang pada akhirnya akan meningkatkan produksi tanaman jagung.
\end{abstract}

Kata kunci: Residu N, serapan hara mikro, tanpa olah tanah

\begin{abstract}
The objectives of this research were to determine the effect of long-term no-tillage (NT) after plowing, $N$ fertilization and residual $N$ on micro nutrient uptakes and corn yield. This research was part of the 30th year of long-term research which was conducted from February to June 2017. This research was arranged in split-split plot design, three factors with four replications. The first factors were TOT, minimum tillage (OTM) after plowing, and intensive tillage (OTI). The second factors were $N$ fertilizer with rate of $0 \mathrm{~kg} \mathrm{~N} \mathrm{ha}^{-1}$ (NO) and $200 \mathrm{~kg} \mathrm{~N}^{-1}$ (N1). Third factors were nitrogen residue of $0 \mathrm{~kg} \mathrm{~N} \mathrm{ha}^{-1}$ (NOr) and $200 \mathrm{~kg} \mathrm{~N} \mathrm{ha}^{-1}$ (N1r). Data were analyzed using Statistic Program 8 and HSD test 5\%. The results of the 30th year research show that after long-term TOT land is recultivated it can increase micro nutrient uptake ( $\mathrm{Fe}, \mathrm{Mn}, \mathrm{Zn}, \mathrm{Cu}$ and $\mathrm{B}$ ) and TOT production (5.99 t ha $\left.{ }^{1}\right)$ is higher when compared to OTM ( $\left.5.23 \mathrm{t} \mathrm{ha}^{-1}\right)$ and OTI $\left(4.43 \mathrm{t} \mathrm{ha}^{-1}\right)$. Fertilization of $200 \mathrm{~kg} \mathrm{~N} \mathrm{ha}^{-1}$ produces micro nutrient uptake (Fe, Mn, Zn, Cu and B) and the treatment of $200 \mathrm{~kg} \mathrm{~N} \mathrm{ha}^{-1}$ (5.90 tha

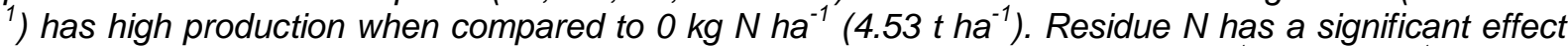
on Mn nutrient uptake and the highest production is at residue of $200 \mathrm{~kg} \mathrm{~N} \mathrm{ha}^{-1}\left(5.59 \mathrm{tha}^{-1}\right)$. This is closely related to the reprocessing on TOT land which stimulates mineralization of soil organic matter and releases nutrients needed and available to plants. In addition, TOT uses the principle of returning crop residues as mulch, thereby increasing soil quality and increasing humidity, availability of ground water, improvement of aggregation and productivity, so that it will increase the amount of plant nutrients in helping plant growth and development which will ultimately increase crop production corn.
\end{abstract}

Keywords: micro nutrient uptake, no-tillage, residual $N$ 


\section{PENDAHULUAN}

Kebutuhan pangan terus mangalami peningkatan seiring dengan peningkatan pertumbuhan penduduk. Sementara ketersedian pangan nasional terus mengalami penurunan. Salah satu bahan pangan yang menjadi fokus pemerintah saat ini adalah jagung, karena selain digunakan sebagai bahan pangan jangung juga digunakan sebagai bahan baku industri dan pakan ternak. Kebutuhan jagung terus mengalami peningkatan disetiap tahunnya, namun pemerintah belum mampu memenuhi kebutuhan tersebut. Hal ini sejalan dengan data BPS, BPS, (2015) menyatakan, bahwa produksi jagung di Indonesia pada tahun 2015 sebesar 19,61 juta ton, sedangkan kebutuhan akan jagung mencapai 21,81 juta ton. Hal ini terlihat jelas bahwa adanya selisih antara produksi dengan kebutuhan pasar sebesar 2,20 juta ton.

Kebutahan lahan terus mengalami peningkatan seiring meningkatnya pertumbuhan penduduk (Utomo, 2015). Sementara lahan sawah yang menjadi tulang punggung pertanian tanaman pangan menghadapi tantangan besar yaitu terjadinya alih fungsi lahan dan berkurangnya pasokan air. Sehingga dibutuhkan suatu strategi untuk meningkatkan kebutuhan pangan nasional, maka lahan kering dipilih sebagai lahan alternatif karena lahan kering memiliki potenasi dan peluang yang besar dalam memenuhi kebutuhan pangan nasional (Utomo, 2012). Hal ini karena luas areal lahan kering di Indonesia mencapai 188,02 juta Ha dan 25,09 juta Ha diantaranya berpotensi untuk area pengembanan tanaman pangan (Sukarman, Mulyani dan Subardja, 2000).

Tingginya laju degradasi tanah wilayah lahan kering menjadi masalah utama. Tingginya degradasi tanah di Indonesia disebabkan oleh erosi, pencucian hara, pemadatan tanah oleh alat berat dan sebagian besar disebabkan oleh sistem olah tanah intensif (OTI) yang berakibat pada menurunnya kualitass tanah in situ, sehingga dalam jangka panjang menyebabkan pertanian yang tidak berkelanjutan (Ardjasa, Ismail, and Effendi, 1981; Utomo, Akbar, dan Yunus, 2016; Utomo, 2012). Pada akhirnya akan berpengaruh dan menjadi ancaman terhadap ketahanan pangan. Oleh karena itu diperlukan teknologi alternatif untuk menekan tingginya laju degradasi tanah dan meningkatkan produktivitas tanah.

Agar lahan kering dapat dimanfaatkan bagi pembangunan pertanian berkelanjutan, maka diperlukan sistem budidaya yang dapat meningkatkan produktivitas tanah dan menekan laju degradasi tanah. Atas dasar tersebut, maka sistem tanpa olah tanah (TOT) digunakan sebagai alternatif dalam meningktakan produktivitas tanah. Hal ini sejalan dengan prinsip TOT yang mengembalikan mulsa sisa tanaman sebelumnya, sehingga mulsa tersebut akan menjadi prekusor bahan organik tanah yang pada akhirnya akan berpengaruh pada tranformasi hara dalam tanah. sehingga mampu memugarkan kualitas tanah in situ terutama dalam memperbaiki sifat fisik, kimia dan biologi tanah (Utomo, 2015).

Namun hasil penelitian tahun ke-28 menunjukan bahwa perlakuan TOT dengan pemberian pupuk $200 \mathrm{~kg} \mathrm{~N} / \mathrm{ha}$ menghasilkan produksi 5,7 ton/ha dan 
tidak berbeda nyata dengan perlakuan OTI dengan pemberian pupuk $200 \mathrm{~kg}$ $\mathrm{N} /$ ha menghasilkan produksi 5,3 ton/ha. Hal ini berkaitan erat dengan makin mengerasnya permukaan tanah pada lahan TOT jangka panjang (BV 1,3 ton/ha) (Akbar, dan Yunus, 2016), sehingga berpengaruh pada perakaran tanaman yang terganggu sehingga serapan hara akan menurun. Oleh karena itu, pada tahun ke-29 ditanaman jagung dengan perlakukan seperti tahun sebelumnya. Kemudian pada tahun ke-30, semua plot TOT dan olah tanah minimum (OTM) dilakukan pengolahan lahan kembali. Sedangkan perlakukan pemupukan $\mathrm{N}$ tetap sama dengan tahun sebelumnya dan adanya dugaan bahwa pemupukan $\mathrm{N}$ jangka panjang menghasilkan residu $\mathrm{N}$, sehingga perlu dilakukan penelitian. Diharapkan setelah diolah kembali, pemanenan hara dan produktivitas tanah TOT jangka panjang akan meningkat kembali.

\section{METODE PENELITIAN}

Penelitian ini merupakan penelitian jangka panjang dan telahan belrjalan selama 30 tahun. Penelitian ini dilaksanakan pada bulan Februari hingga penelitian dilaksanakan pada bulan juni 2017. Penanaman dilakaksanakan dilahan percobaan Politeknik Negeri Lampung dan analisis tanah dilakukan di balai penelitian tanah di Bogor. Penelitian ini dirancang dengan rancangan split-split plot 3 faktor dengan 4 ulangan. Faktor pertama adalah sistem tanah yaitu T0: tanpa olah tanah (TOT), T1: olah tanah minimum (OTM) dan T2: olah tanah intensif (OTI). Faktor ke dua yaitu pemupukan nitrogen jangka panjang N0 (tanpa pemupukan N) dan $\mathrm{N} 1\left(200 \mathrm{~kg} \mathrm{~N}^{-1}\right)$. Faktor ke tiga residu nitrogen, residu NOr (residu $0 \mathrm{~kg} \mathrm{~N}^{-1}$ ) dan N1r (residu $200 \mathrm{~kg} \mathrm{~N} \mathrm{ha}^{-1}$ ). Uji homogenitas data dengan uji Barlet dan aditivitas dengan uji Tukey. Selanjutnya data dianalisis ragam menggunakan program statistik 8 dan uji lanjutan dengan menggunakan uji BNJ pada taraf $5 \%$.

Bahan-bahan yang digunakan pada penelitian ini adalah benih jagung hibrida (Pioner 27), herbisida Roundup dan Lindomin, pupuk Urea, SP-36, dan $\mathrm{KCl}$, dan bahan-bahan lain yang mendukung penelitian. Sedangkan alat-alat yang digunakan dalam penelitian ini adalah cangkul, koret, bor tanah, timbangan, tali plastik, litel bag, benang, alat tulis, alat untuk kebutuhan analisa di laboratorium, dan alat-alat lain yang mendukung penelitian. Penanaman benih jagung hibrida dengan cara membuat lubang tanam dengan jarak $75 \mathrm{~cm} \times 25 \mathrm{~cm}$. Jarak tanaman antarpetak percobaan yaitu $0,5 \mathrm{~m}$. Variabel pengamatan dalam penelitian ini yaitu brangkasan tanaman, serapan hara mikro ( $\mathrm{Fe}, \mathrm{Mn}, \mathrm{Cu}, \mathrm{Zn}$, dan $\mathrm{B})$ dan produksi jagung.

\section{HASIL DAN PEMBAHASAN}

\section{Sifat Kimia dan Hara Mikro Tanah}


Hasil analisis tanah awal (sebelum pengolahan) menunjukkan bahwa pemupukan $\mathrm{N}$ berpengaruh nyata terhadap sifat kimia tanah seperti $\mathrm{pH}, \mathrm{N}$ total, $\mathrm{Na}$ dan Fe. Sedangkan sistem olah tanah berpengaruh nyata terhadap siaft kimia seperti C-organik, dan $\mathrm{Na}$. Sedangkan pemupukan $\mathrm{N}$ dan sistem olah tanah tidak berpengaruh nyata terhadap sserapan unsur S, Cu, Zn dan B. Sedangkan sifat kimia seperti KTK, K, Ca, Mg, dan Mn tidak homogen. Hal ini menunjukan bahwa tanah yang digunakan dalam penelitian ini merupakan tanah yang telah mengalami pelapukan lanjut yang dicirikan dengan karakteristik sifat kimia tanah yang memiliki kesuburan tanah rendah (Utomo, 2012).

Tabel 1. Sifat Kimia dan Hara Mikro Tanah Awal Kedalaman 0-20 cm.

\begin{tabular}{|c|c|c|c|c|c|c|}
\hline \multirow{2}{*}{$\begin{array}{c}\text { Sifat kimia } \\
\text { tanah dan hara } \\
\text { tanaman }\end{array}$} & \multicolumn{6}{|c|}{ Perlakuan } \\
\hline & $\begin{array}{l}\text { T2N } \\
0\end{array}$ & T1No & TONO & T2N1 & T1N1 & TON1 \\
\hline $\mathrm{KTK}\left(\mathrm{cmol}_{\mathrm{c}} \mathrm{kg}^{-1}\right)$ & 6,24 & 6,42 & 6,31 & 6,37 & 6,31 & 6,26 \\
\hline $\mathrm{pH}\left(\mathrm{H}_{2} \mathrm{O}\right)$ & 6,02 & 6,05 & 6,11 & 5,80 & 5,76 & 5,84 \\
\hline $\mathrm{Fe}\left(\mathrm{g} \mathrm{kg}^{-1}\right)$ & 55,2 & 55,3 & 57,6 & 54,4 & 53,6 & 54,3 \\
\hline $\operatorname{Mn}\left(\mathrm{mg} \mathrm{kg}^{-1}\right)$ & 1260 & 1385 & 1198 & 1530 & 1255 & 1281 \\
\hline $\mathrm{Cu}\left(\mathrm{mg} \mathrm{kg}^{-1}\right)$ & $\begin{array}{l}17,0 \\
0\end{array}$ & 17,00 & 17,75 & 17,25 & $\begin{array}{l}16,2 \\
5\end{array}$ & 16,50 \\
\hline $\mathrm{Zn}\left(\mathrm{mg} \mathrm{kg}^{-1}\right)$ & $\begin{array}{l}62,0 \\
0\end{array}$ & 66,25 & 64,00 & 62,75 & $\begin{array}{l}61,2 \\
5\end{array}$ & 61,00 \\
\hline $\mathrm{B}\left(\mathrm{mg} \mathrm{kg}^{-1}\right)$ & 9,75 & 10,00 & 9,50 & 9,75 & 8,75 & 10,50 \\
\hline
\end{tabular}

Keterangan: T0 (tanpa olah tanah); T1 (olah tanah minimum); T2 (olah tanah Intensif; N0 (0 kg N ha $\left.{ }^{-1}\right)$; N1 (200 kg N ha $\left.{ }^{-1}\right)$.

\section{Serapan Hara Mikro Tanaman Jagung}

Dari hasil penelitian tahun ke-30 setelah lahan TOT dilakukan pengolahan kembali (Gambar 1) menunjukan bahwa pada perlakuan sistem olah tanah berpengaruh nyata terhadap serapan hara mikro (Fe, Mn, Zn dan B) tanaman jagung. Pada sistem olah tanah menunjukan bahwa perlakuan T0 (TOT) memiliki serapan hara mikro ( $\mathrm{Fe}, \mathrm{Mn}, \mathrm{Zn}$ dan $\mathrm{B}$ ) tertinggi bila dibandingkan dengan serapan hara T1 (OTM) dan T2 (OTI). Pada gambar 1 menyatakan, bahwa perlakuan T0 (TOT) berbeda nyata dengan perlakuan T2 (OTI), namun tidak berbeda nyata dengan perlakuan T1 (OTM).

Hal ini berkaitan erat dengan pengolahan kembali lahan TOT jangka panjang dengan prinsip pengembalian sisa tanaman sebagi mulsa, berbeda dengan OTI yang tidak menggunakan prinsip pengembalian sisa tanaman sebagai mulsa. Adanya pengembalian sisa tanaman sebagai mulsa pada lahan TOT akan memberikan layanan ekosistem dalam perbaikan kualitas tanah. Pengembalian sisa tanaman sebelumnya sebagai mulsa berperan 
penting dalam meningkatkan kelembaban tanah, ketersediaan air tanah, perbaikan sifat fisik tanah seperti perbaikan porositas dan penguatan agregasi tanah sehingga mampu meningkatan kualitas pada ladan TOT.

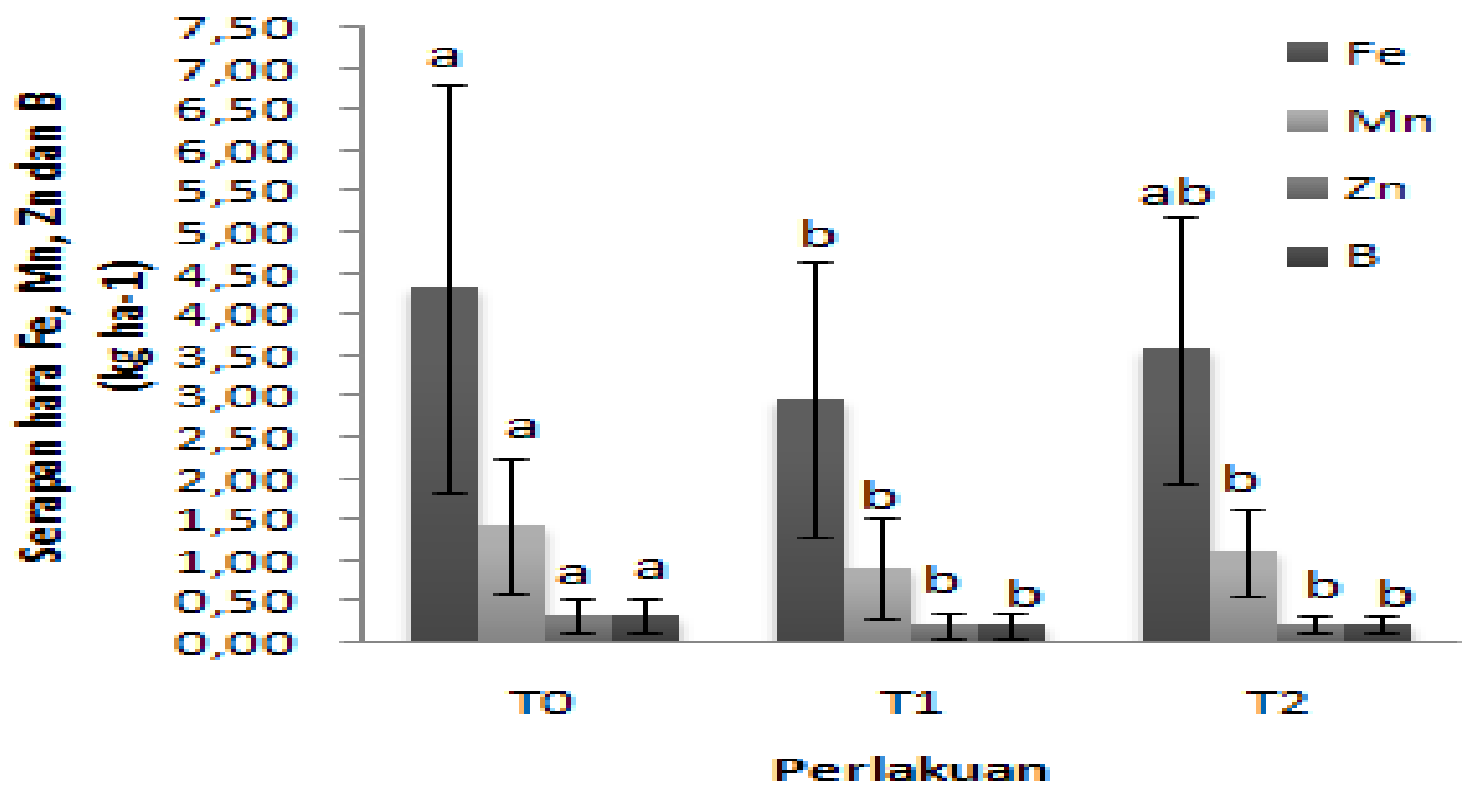

Gambar 1. Pengaruh Sistem Olah Tanah Jangka Panjang terhadap Serapan Hara Mikro Fe, Mn, Z dan B. T0 (tanpa olah tanah); T1 (olah Tanah minimum); T2 (olah Tanah intensif).

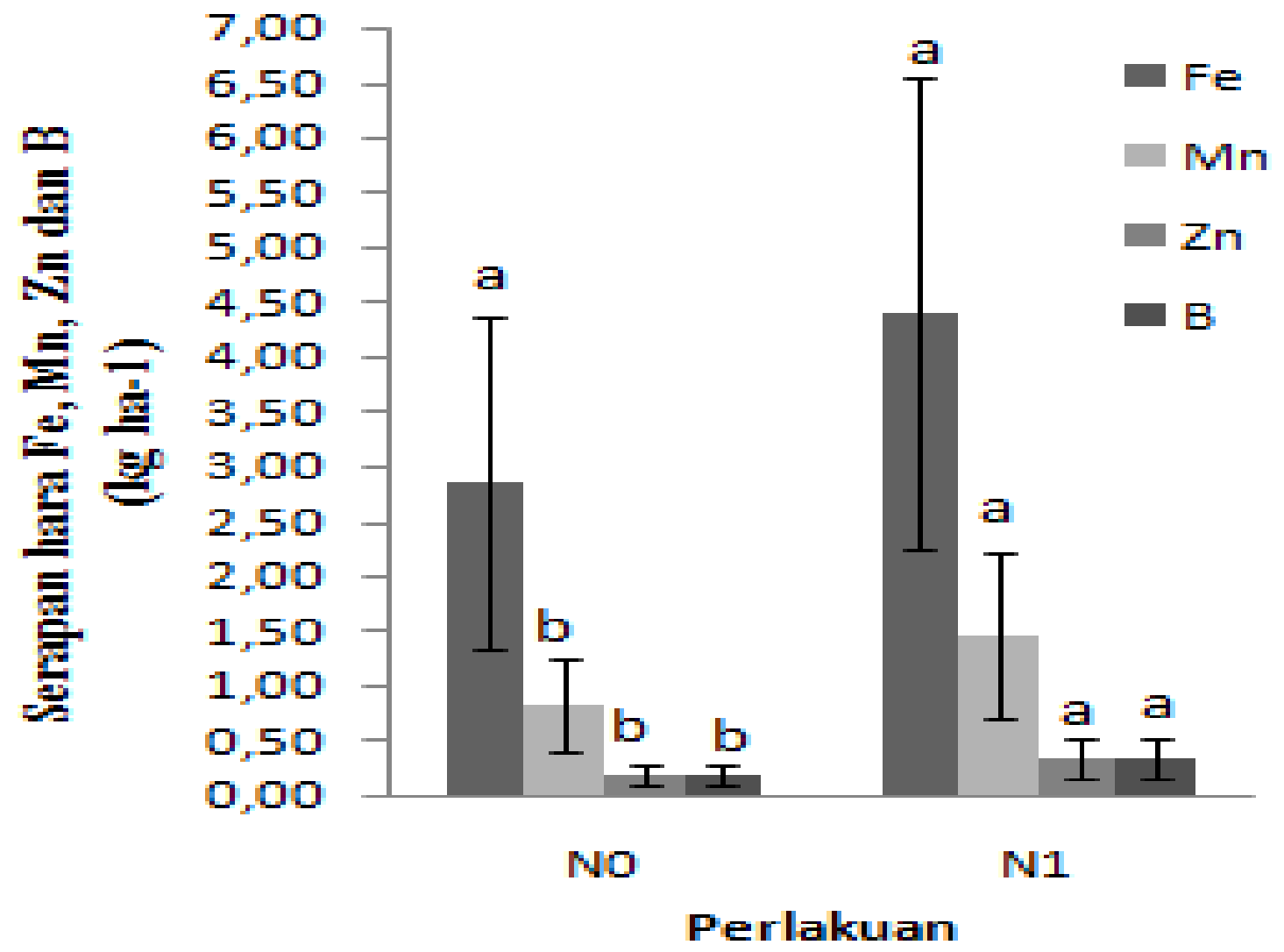

Gambar 2. Pengaruh Pemupukan terhadap Serapan Hara Mikro Fe, Mn, Zn dan B. N0 (0 kg N ha-1); N1 (200 kg N ha $\left.{ }^{-1}\right)$. 
Hal ini sejalan dengan pernyataan Utomo, (Utomo, (2004)] yang menyatakan bahwa pemberian mulsa pada lahan TOT mampu menurunkan evaforasi tanah, meningkatkan ketersediaan air tanah yang disebabkan oleh meningkatnya karbon organik tanah hasil dekomposisi mulsa in situ, menekan tingginya laju erosi dan pencucian hara dan pada akhirnya akan berpengaruh terhadap ketersediaan hara mikro dan dapat diserap oleh tanaman jagung (Utomo, 2012). Sejalan juga dengan pernyataan Salam, (2012); Utomo, (2012); Utomo, (2016) yang menyatakan, bahwa pengembalian sisa tanaman sebagai mulsa mampu memperbaiki porositas tanah dan pemugaran sifat-sifat tanah lainnya dalam mendukung penyerapan hara yang dibutuhkan oleh tanaman. Selain itu juga pengembalian sisa tanaman sebagai mulsa pada lahan TOT mampu meningktkan kelembaban tanah, kandungan bahan organik tanah, agregasi tanah dan menurunkan ketahanan penetrasi tanah dan memiliki ruang pori tersedia lebih banyak bila dibandingkan OTM dengan penambahan mulsa (Adrinal, Saidi, dan Gusmini, 2012)].

Dari hasil penelitian tahun ke-30 setelah lahah TOT dilakukan pengolahan kembali (Gambar 2) menunjukan bahwa perlakuan pemupukan N jangka panjang berpengaruh nyata terhadap semua serapan hara mikro (Fe, $\mathrm{Mn}, \mathrm{Zn}$ dan B) tanaman jagung. Dari grafik tersebut terlihat bahwa serapan hara mikro (Fe, Mn, Zn dan B) tertinggi terdapat pada perlakuan N1 (200 kg N $\left.\mathrm{ha}^{-1}\right)$ dan berbeda nyata dengan perlakuan N0 $\left(0 \mathrm{~kg} \mathrm{~N}^{-1}\right)$. Hal ini berkaitan erat dengan kandungan hara mikro ( $\mathrm{Fe}, \mathrm{Mn}, \mathrm{Zn}$ dan $\mathrm{B}$ ) didalam tanah dan berkaitan juga dengan terjadinya pertukaran anion dan kation yang ada dalam koloid tanah. Semakin tingginya aplikasi urea ke dalam tanah akan menyumbangkan $\mathrm{N}$ dalam jumlah besar yang pada akhirnya kandungan $\mathrm{N}$ didalam tanah akan meningkat.

Tingginya konsentrasi $\mathrm{N}$ didalam tanah dalam bentuk $\mathrm{NH}_{4}{ }^{+}$dalam konsentrasi tinggi, sehingga ion $\mathrm{Fe}^{2+}, \mathrm{Mn}^{2+}, \mathrm{Zn}^{2+}$ dan $\mathrm{B}$ akan terusir dari koloid tanah dan digantikan dengan $\mathrm{NH}_{4}^{+}$. Terlepasnya ion $\mathrm{Fe}^{2+}, \mathrm{Mn}^{2+}, \mathrm{Zn}^{2+}$ dan $\mathrm{B}$ dari koloid tanah, maka akan tersedia dan dapat diserap oleh tanaman melalui mekanisme alisan masa, difusi dan intersepsi akar. Hal ini sejalan dengan pernyataan Salam, (2012) dan Utomo, (2012) menyatakan, bahwa tingginya konsentrasi $\mathrm{NH}_{4}{ }^{+}$yang dimasukkan ke dalam kolom tanah akan terjadi pertukaran anion dan kation. Sehingga anion dan kation yang terikat dalam kolom tanah akan terlepas dan digantikan dengan $\mathrm{NH}_{4}{ }^{+}$.

Dari hasil penelitian tahun ke-30 setelah lahan TOT dilakukan pengolahan kembali (Gambar 3) menunjukan bahwa pada perlakuan residu pemupukan $\mathrm{N}$ jangka panjang memberikan pengaruh nyata terhadap serapan hara mikro $\mathrm{Mn}$. Hal ini karena tidak semua $\mathrm{N}$ dari pemupukan $\mathrm{N}$ diserap oleh tanaman dan tertinggal didalam tanah. Mengacu pada kandungan $\mathrm{N}$-total tanah awal dan kandungan hara $\mathrm{Mn}$ didalam tanah. Tingkat pemupukan $\mathrm{N}$ yang tinggi dapat menginduksi lebih banyak $\mathrm{N}$ tanah yang tertinggal pada kedapa lapisan top soil atau pada kedalaman $0-10 \mathrm{~cm}$. Hal ini sejalan dengan penelitian Gercia et al. (2007) dan Utomo, (2013) yang menyatakan, bahwa tingkat pemupukan $\mathrm{N}$ jangka panjang memiliki efek residu terhadap $\mathrm{N}$-total tanah pada kedalaman $0-20 \mathrm{~cm}$. 


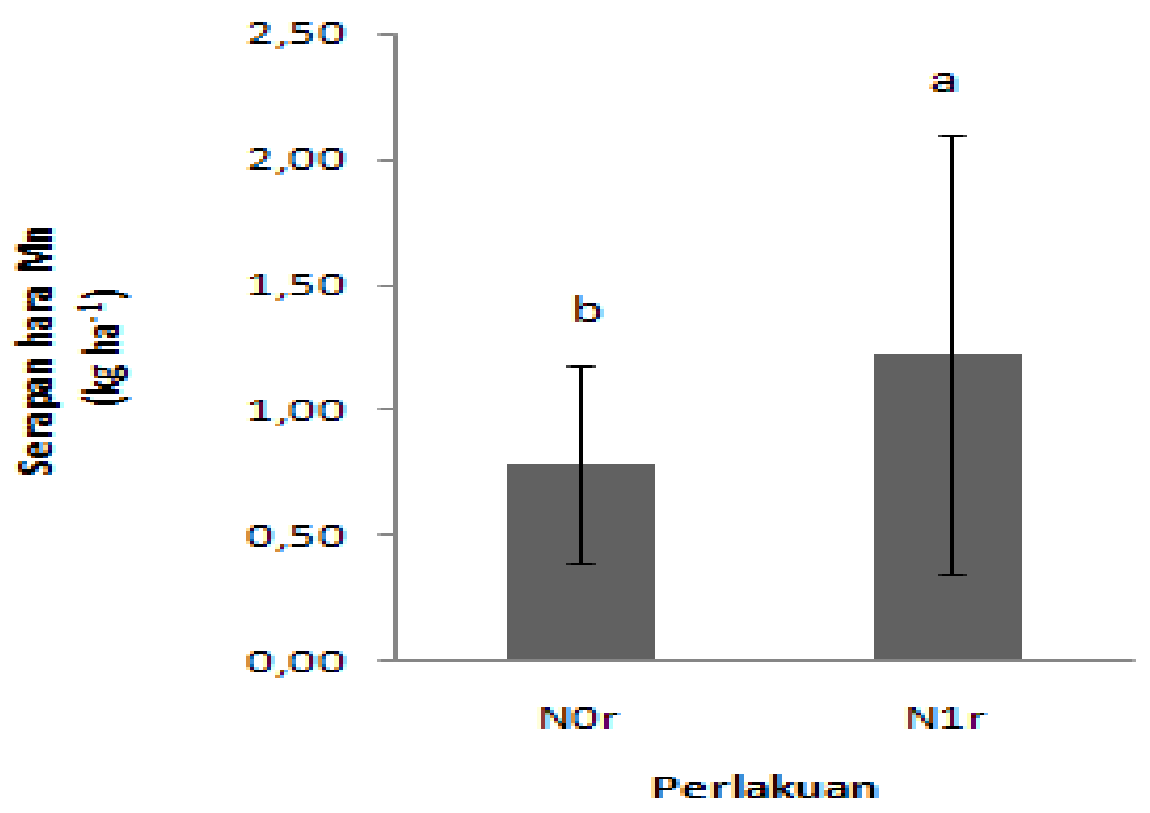

Gambar 3. Pengaruh Sistem Olah Tanah Jangka Panjang, Pemupukan $N$ dan Residu N terhadap Serapan Hara Mikro Mn. NOr $\left(0 \mathrm{~kg} \mathrm{~N} \mathrm{~h}^{1}\right)$; N1r (200 kg N ha- $\left.{ }^{-1}\right)$.

Selain dari pemupukan $\mathrm{N}$ jangka panjang, residu $\mathrm{N}$ juga berasal dari sisa tanaman yang digunakan sebagai mulsa. Hal ini sejalan dengan pernyataan Utomo et al. (2012); Utomo, (2015), bahwa rerata mulsa yang dikembalikan setiap musim pada lahan OTK sebesar $6 \mathrm{t} \mathrm{ha}^{-1}$ untuk jagung dan $2 \mathrm{t} \mathrm{ha}^{-1}$ untuk tanaman kacang-kacangan.

Dari hasil penelitian tahun ke-30 setelah lahan TOT dilakukan pengolahan kembali (Gambar 4) menunjukan bahwa pada perlakun interaksi pemupukan $\mathrm{N}$ dengan residu pemupukan $\mathrm{N}$ jangka panjang memberikan pengaruh yang nyata terhadap serapan hara B.

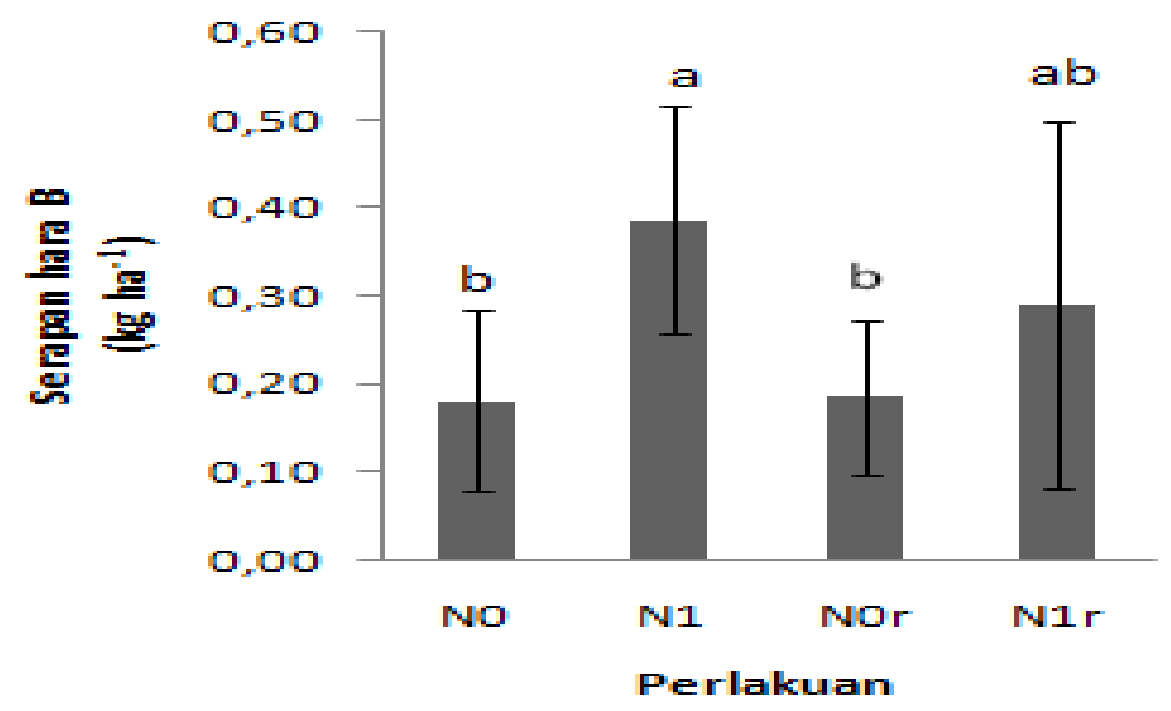

Gambar 4. Pengaruh Interaksi Pemupukan $N$ dan Residu N Terhadap Serapan Hara Mikro B. N0 (0 kg N ha $\left.{ }^{-1}\right)$; N1 (200 kg N ha $\left.{ }^{-1}\right)$; NOr (0 kg N ha $\left.{ }^{-1}\right)$; N1r (200 kg N ha $\left.{ }^{-1}\right)$. 
Interaksi antara pemupukan $\mathrm{N}$ dengan residu pemupukan $\mathrm{N}$ memperlihatkan hasil tertinggi pada perlakuan pemupukan $\mathrm{N}$ optimal $(200 \mathrm{~kg}$ $\mathrm{N}$ ha ${ }^{-1}$ ) tidak berbeda nyata dengan perlakuan N1r (residu $200 \mathrm{~kg} \mathrm{~N} \mathrm{ha}^{-1}$ ), tetapi berbeda nyata dengan perlakuan No $\left(0 \mathrm{~kg} \mathrm{~N} \mathrm{ha}^{-1}\right)$ dan perlakuan NOr (residu $0 \mathrm{~kg} \mathrm{~N} \mathrm{ha}^{-1}$ ). Hal ini berkaitan erat dengan pemerian pemupukan $\mathrm{N}$ yang tinggi, sehingga menyuplai kandungan $\mathrm{N}$ dalam tanah meningkat. Salam, (2012) menyatakan tingginya $\mathrm{NH}_{4}{ }^{+}$di masukakan kedalam tanah relatif tinggi, sehingga terjadi pertukaran kation yang mengakibatkan ion $\mathrm{B}$ terusir dari koloid tanah. Pemupukan $\mathrm{N}$ yang optimal dapat menurunkan derajat keasaman tanah $(\mathrm{pH})$ yang akan berakibat pada ketersedian $\mathrm{B}$ didalam tanah. Tersediannya B pada air tanah akan berpengaruh pada penyerapan hara oleh akar tanaman (Salam, 2012).

Pola tanggap serapan hara $\mathrm{Cu}$ terhadap interaksi ketiga perlakuan (interaksi siatem olah tanah dengan pemupukan $\mathrm{N}$ dan residu $\mathrm{N}$ ). Serapan hara Cu tertinggi terlihat pada perlakuan N1rT0 (residu pemupukan N $200 \mathrm{~kg}$ $\mathrm{N} \mathrm{ha}^{-1}$ dan sistem tanpa olah tanah).

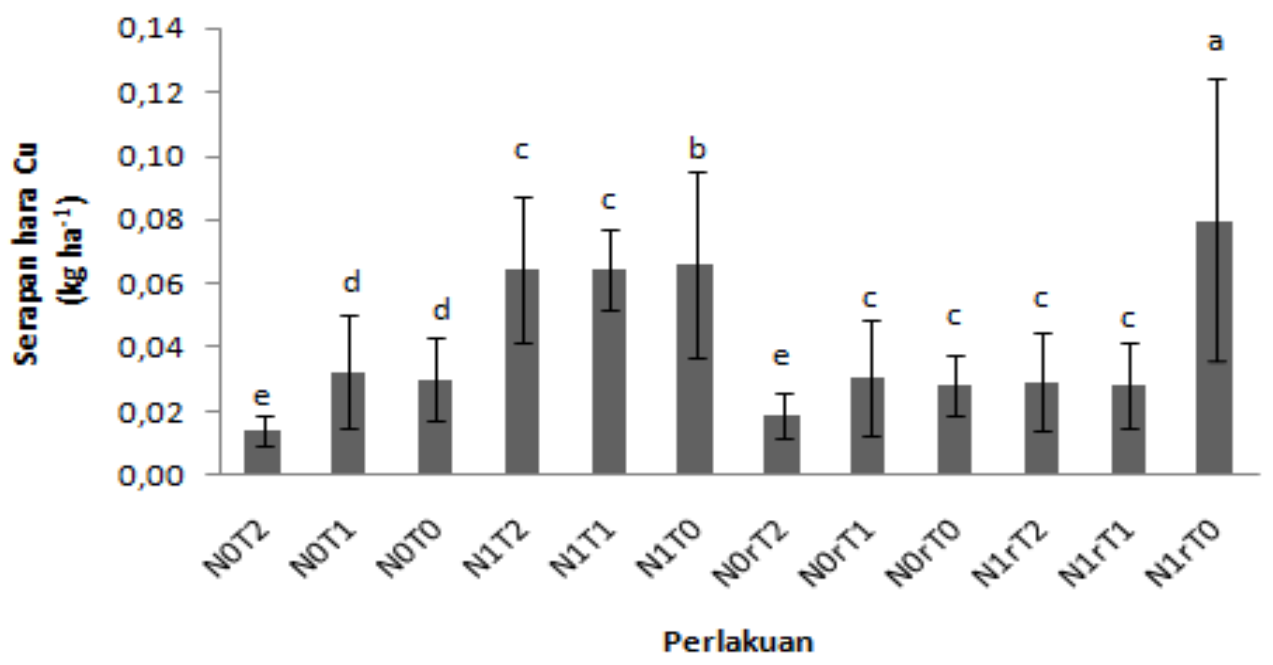

Gambar 5. Pengaruh Interaksi Sistem Olah Tanah, Pemupukan $\mathrm{N}$ dan Residu $\mathrm{N}$ terhadap Serapan Hara Mikro Cu. N0 (0 kg N ha $\left.{ }^{-1}\right)$; N1 (200 kg N ha $\left.{ }^{-1}\right)$; NOr $(0 \mathrm{~kg} \mathrm{~N}$ $\left.\mathrm{ha}^{-1}\right)$; N1r (200 kg N ha $\left.{ }^{-1}\right)$.

Dari hasil penelitian tahun ke-30 setelah lahan TOT dilakukan pengolahan kembali, terlihat bahwa perlakuan N1rT0 (interaksi residu $200 \mathrm{~kg}$ $\mathrm{N}$ ha ${ }^{-1}$ dan sistem tanpa olah tanah) terlihat berbeda nyata dengan perlakuan lainnya. Hal ini karena pada perlakuan TOT jangka panjang setelah dilakukan pengolahan mampu memperbaiki kualitas tanah, dimana pada perlakuan TOT menggunakan prinsip pengembalian sisa tanaman sebelumnya sebagai mulsa.

Pengembalian sisa tanaman sebagai mulsa pada lahan TOT mampu meningkatkan kelembaban tanah, kandungan bahan organik tanah, agregasi dan menurunkan ketahanan penetrasi tanah. Hal ini sejalan dengan pernyataan Adrinal [9] pada perlakuan TOT dengan penambahan mulsa 
memiliki pori air tersedia lebih banyak bila dibandingkan OTM dengan penambahan mulsa.

Selain itu udara tipis atar mulsa dengan permukaan tanah akan berpengaruh pada pematahan pergerakan uap air ke atas yang pada akhirnya berakibat pada menurunnya kehilangan air melalui evaporasi dan kelembaban tanah meningkat (Blevins, and Frye, 1994; Utomo, 2004) dalam Utomo, (2012). Meningkatnya kualitas tanah pada lahan TOT menunjukkan bahwa TOT mampu memberikan ketersedian hara lebih baik bila dibandingkan OTI. Hal ini berkaitan dengan penyerapan unsur hara mikro pada tanaman untuk mendukung pertumbuhan dan produksi tanaman jagung.

\section{Produksi Tanaman Jagung}

Hasil produksi jagung tahun ke-29 (2017) sebelum lahan TOT diolah kembali memperlihatkan bahwa hasil produksi jagung tidak resposif terhadap sistem olah tanah, namun lebih responsif terhadap interaksi sistem olah tanah dengan pemupukan $\mathrm{N}$ jangka panjang. Pada tahun ke-29 produksi tertinggi terlihat pada perlakuan OTM, walaupun tidak berbeda nyata dengan perlakuan OTI dan TOT (Agsari, 2018 unpublis).

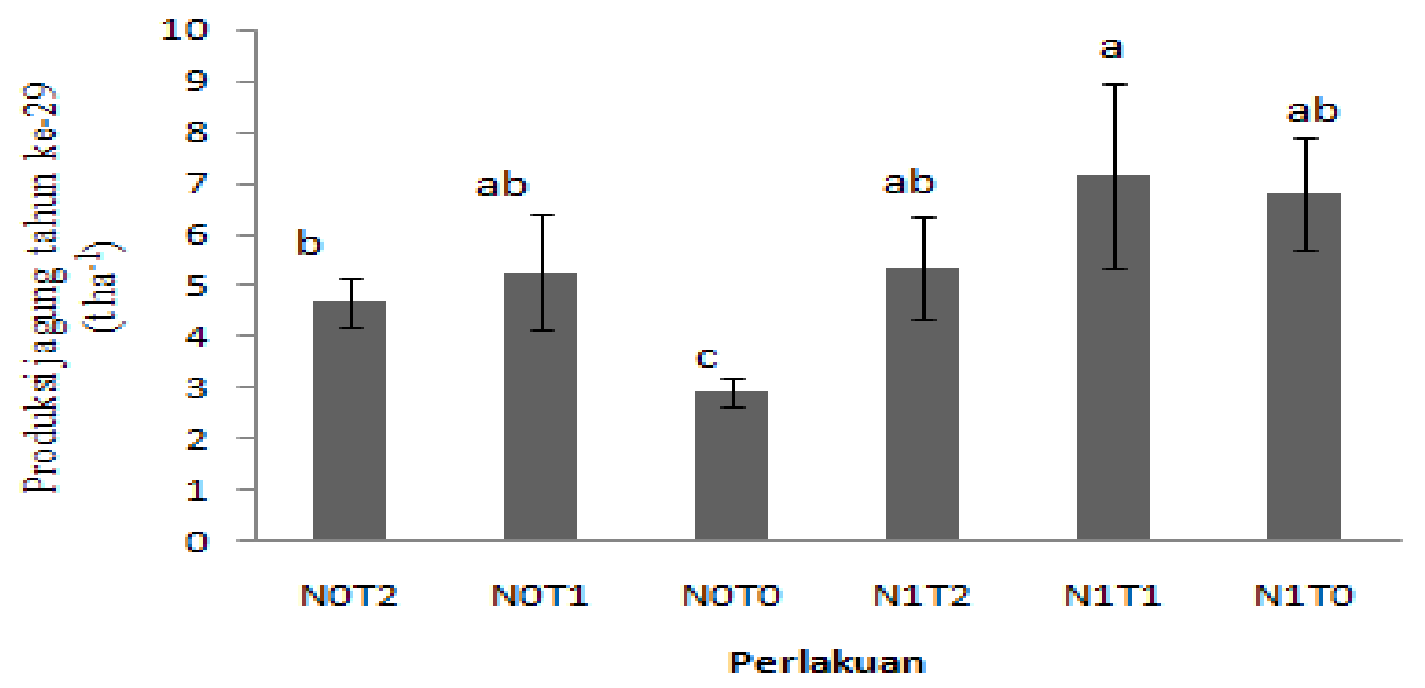

Gambar 6. Pengaruh tanpa olah tanah dan pemupukan nitrogen jangka panjang terhadap produksi tanaman jagung tahun ke-29. T0 (tanpa olah tanah); T1 (olah tanah minimum) dan T2 (olah tanah intensif); N0 (0 kg N ha $\left.{ }^{-1}\right) ; \mathrm{N} 1\left(200 \mathrm{~kg} \mathrm{~N} \mathrm{ha}^{-1}\right)$.

Hal ini berkaitan dengan terjadinya perubahan sifat fisik tanah terutama terjadi peningkatan kekerasan tanah pada lahan TOT. Mengerasanya permukaan tanah pada lahan TOT akan berakibat pada pemadatan tanah, sehingga akan berpengaruh terhadap porositas tanah yang pada akhirnya akan mengganggu penyerapan hara oleh tanaman dan akan menurunkan produksi. Hal ini sejalan dengan penelitian Utomo [3] yang menyatakan bahwa peningkatan kekerasan permukaan TOT terlihat lebih tinggi bila dibandingkan 
OTI, peningkatan kekerasan tanah pada lahan TOT akan berakibat pada pemadatan tanah

Juga berpengaruh terhadap porositas tanah yang pada akhirnya kan berpengaruh pada penurunan kualitas dan kesuburan tanah, sehingga akan berakibat pada penurunan produktivitas lahan yang pada akhirnya akan berpengaruh pada penurunan produksi jagung (Utomo, 2012).

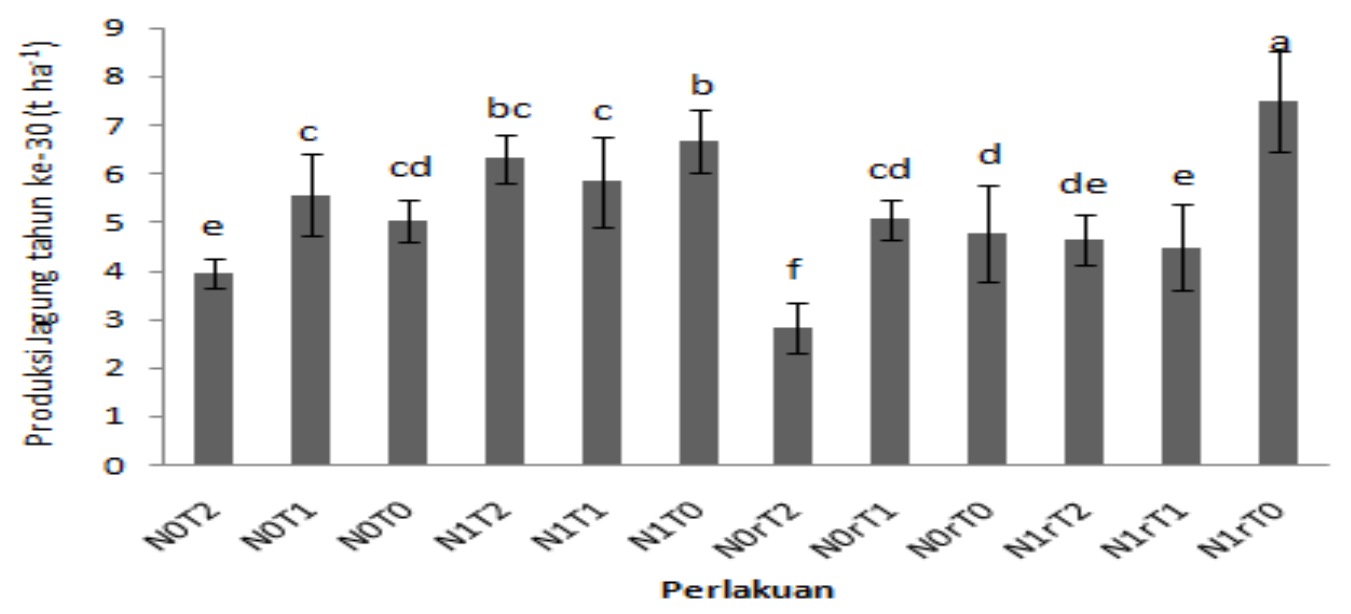

Gambar 7. Pengaruh tanpa olah tanah pemupukan $\mathrm{N}$ dan residu $\mathrm{N}$ jangka panjang setelah diolah kembali terhadap produksi tanaman jagung. T0 (tanpa olah tanah) T1 (olah tanah minimum); dan T2 (olah tanah intensif); No (0 kg N ha $\left.{ }^{-1}\right) ; \mathrm{N} 1(200 \mathrm{~kg} \mathrm{~N}$ ha $^{-1}$ ); NOr (residu $0 \mathrm{~kg} \mathrm{~N} \mathrm{ha}^{-1}$ ); N1r (residu $200 \mathrm{~kg} \mathrm{~N} \mathrm{ha}^{-1}$ ).

Setelah lahan TOT diolah kembali (tahun ke-30) produksi jagung pada lahan TOT mengalami peningkatan kembali dan bahkan menghasilkan produksi yang lebih tinggi dari biasanya dan tahun tanam sebelumnya (tahun ke-29) (Aksari, 2017). Hal ini menunjukkan bahwa pada perlakuan TOT jangka panjang yang diolah kembali (tahun ke-30) baik dengan pemupukan $\mathrm{N}$ optimum (200 kg N ha-1) maupun tanpa pemupukan $\mathrm{N}(0 \mathrm{~kg} \mathrm{~N} \mathrm{ha-1})$ memberikan hasil produksi jagung lebih tinggi bila dibandingkan dengan produksi pada lahan TOT sebelum diolah (tahun ke-29) dengan perlakuan pemupukan $\mathrm{N}$ optimum (200 $\left.\mathrm{kg} \mathrm{N}^{-1}\right)$ maupun tanpa pemupukan $\mathrm{N}(0 \mathrm{~kg} \mathrm{~N}$ ha $\left.^{-1}\right)$.

Hasil produksi jagung pada tahun ke-30 (Gambar 7) menunjukan bahwa respon produksi tanaman pada perlakuan TOT setelah dilakukan pengolahan kembali secara nyata menghasilkan produksi lebih tinggi $\left(5,99 \mathrm{t} \mathrm{ha}^{-1}\right)$ bila dibandingan dengan perlakuan OTI $\left(4,43 \mathrm{t} \mathrm{ha}^{-1}\right)$. Meningkatnya produksi pada perlakuan TOT setelah dilakukan pengolahan kembali terlihat pada perlakuan N1rT0 (residu $200 \mathrm{~kg} \mathrm{~N} \mathrm{ha}^{-1}$ dan tanpa olah tanah). Hali ini menunjukan bahwa adanya akumulasi hara hasil dari dekomposisi serasah pada lahan TOT. selain itu juga pada lahan TOT setelah dilakukan pengolahan kembali terjadi mineralisasi dan dapat dimanfaatkan oleh tanaman sebagai tambahan unsur hara. Meningkatnya hara tersedia dan dapat diserap oleh tanaman, sehingga membantu tanaman dalam memproses pertumbuhan dan perkembangan yang pada akhirnya akan berpengaruh pada peningkatan produksi. Hal ini sejaln dengan penelitian Utomo [3] menyatakan, bahwa lahan TOT yang 
diolah kembali akan memacu mineralisasi bahan organik tanah dan melepaskan hara yang dibutuhkan oleh tanaman dan tersedia bagi tanaman sehingga akan membantu dalam peningkatan produksi jagung.

Dari hasil penelitian jangka panjang selama 30 tahun berturut-turut menunjukan bahwa pemupukan $\mathrm{N}$ jangka panjang memperlihatkan adanya residu hara yang dapat dimanfaatkan pada musim tanam selanjutnya dalam meningkatkan produksi. Residu $\mathrm{N}$ jangka panjang memberikan pengaruh nyata terhadap peningkatan produksi tanaman jagung pada tahun ke-30. Hal ini berkaitan erat dengan pengembalian sisa tanaman sebagai mulsa selama 30 tahun berturut-turut mampu mensubsidi atau menyediakan unsur hara yang dibutuhkan oleh tanaman dalam meningkatkan produksi jagung. Hal ini sejalan dengan penelitian Anggraini, Nuraini, dan Prayoga, (2017)] bahwa pemberian pupuk NPK bebasis amonium nitrat dan petrobiofertil secara terus-menerus dalam dosis tinggi mampu memberikan residu $\mathrm{N}$ yang dapat berpengaruh nyata terhadap ketersedian unur hara NPK di tahun tanama selanjutnya.

Pemanfaatan residu tanaman sebelumnya tanpa manipulasi mekanis permukaan lahan yang berlebihan, sehingga pertanian dengan teknologi TOT dapat meningkatkan kandungan bahan organik tanah dan kesuburan tanah terutama pada permukaan tanah. Utomo, Frye, and Blevins, (1990) meningkatnya kelembaban tanah pada lahan TOT akibat adanya mulsa akanmemacu serapan hara, sehingga dapat meningkatkan produksi jagung. Adanya residu tanaman pada lahan TOT akan memacu aktivitas biota tanah yang kemudian akan mempercepat proses dekomposisi bahan organik. Temuan terakhir yang dilaporkan oleh Miura et al. (2016) menunjukkan bahwa TOT mampu mengurangi pengaruh negatif pemupukan $\mathrm{N}$ terhadap komunitas mikrobiologi tanah. Meningkatnya kandungan bahan organik tanah dan kesuburan tanah yang pada akhirnya akan meningkatkan produktivitas lahan. Meningkatnya produktivitas lahan maka akan meningkatkan pula produksi tanaman.

Pada penelitian jangka panjang selama 30 tahun menunjukan pola khas produksi jagung pada sistem olah tanah. Pada perlakuan TOT baik residu 200 $\mathrm{kg} \mathrm{N} \mathrm{ha}^{-1}$ maupun dengan pemupukan $200 \mathrm{~kg} \mathrm{~N}$ ha $^{-1}$ memberikan hasil produksi jagung tertinggi $\left(5,99 \mathrm{tha}^{-1}\right)$ bila dibandingkan dengan perlakuan OTI $\left(4,43 \mathrm{~kg} \mathrm{~N} \mathrm{ha}^{-1}\right)$.

\section{SIMPULAN}

TOT jangka panjang setelah dilakukan pengolahan kembali dapat meningkatakan serapan hara mikro (Fe, Mn, Zn, Cu dan B) dan produksi TOT (5,99 ha-1) lebih tinggi bila dibandingkan dengan OTM (5,23 ha-1) dan OTI (4,43 ha-1). Pemupukan $200 \mathrm{~kg} \mathrm{~N}$ ha-1 menghasilkan serapan hara mikro (Fe, $\mathrm{Mn}, \mathrm{Zn}, \mathrm{Cu}$ dan B) dan perlakuan $200 \mathrm{~kg} \mathrm{~N}$ ha-1 (5,90 t ha -1) memiliki produksi yang tinggi bila dibandingkan dengan $0 \mathrm{~kg} \mathrm{~N}$ ha-1 (4,53 t ha-1). Residu $\mathrm{N}$ berpengaruh nyata terhadap serapan hara $\mathrm{Mn}$ dan produksi tertinggi pada residu $200 \mathrm{~kg} \mathrm{~N}$ ha-1 (5,59 tha-1). 


\section{DAFTAR PUSTAKA}

Adrinal, A. Saidi, dan Gusmini. 2012. Perbaikan Sifat Fisik- Kimia Tanah Psamment dengan Pemulsaan Organik dan Olah Tanah Konservasi pada Budidaya Jagung. Journal Solum 9(1)S: 25-35.

Anggraini, N. F., Y. Nuraini, dan C. Prayoga. 2017. Efek Residu Pemupukan NPK Berbasis Amonium dan Nitrat terhadap Ketersediaan Hara, Kelimpahan Bakteri serta Pertumbuhan Dan Hasil Tanaman Sawi. Jurnal Tanah dan Sumberdaya Lahan 4(1): 481-492.

Ardjasa, W.S., I.G. Ismail, and S. Effendi. 1981. The Application of Dowpon M on Alang-Alang. APWSS Conferences. Bangalore, India.

Garcia, J.P., C.S. Woertmann, M. Mamo, R. Drijbr, and D. Tarkalson. 2007. One-Time Tillage of No-Till: Effects on Nutrients, Mycorrhizae, and Uptake. Jurnal Agronomy 99:10 9. 2007.

Blevins, R.L, and W.W, Frye. 1994. Conservation Tillage, an Ecological Approach to Soil Management. Advance in Agronomy 51.

Badan Pusat Statistik. 2015. Data Produktivitas Jagung Indonesia pada tahun 2015" (http://www.bps.go.id). Diakses pada 8 Juli 2015.

Salam, A. K. 2012. IImu Tanah Fundamental. Global Madani Pres. Bandar Lampung. $362 \mathrm{hlm}$.

Sukarman, A. Mulyani dan D. Subardja. 2000. Identifikasi Lahan Kering Potensial untuk Pengembangan Tanaman Pangan. Diakses pada tanggal 10 Maret 2020.

Utomo, M., W.W Frye, and R.L Blevins. 1990. Sustaining Soil Nitrogen for Corn Using Hairy Vetch Cover Crop". Journal Agronomy 62(5): 979-983.

Utomo. M. 2012. Tanpa Olah Tanah. Teknologi Pengolahan Pertanian Lahan Kering. Lembaga Penelitian Universitas Lampung. Bandar Lampung.

Utomo, M., H. Buchari, I. S. Banuwa, dan Fernand. 2012. Carbon Storage and Carbon Dioxide Emission As Influenced Bylong-Term Conservation Tillage and Nitrogen Fertilizationin Corn-Soybean Rotation. Journal Tropical Soils 17(1): 75-84.

Utomo, M., I.S Banuwa, H. Buchari, Y. Anggraini, and Betharia. 2013. Long term Tillage and Nitrogen Fertilization Effects on Soil Properties and Crop Yields. Journal Tropical Soils 2(18): 131-139.

Utomo. M. 2004. Olah Tanah Konservasi untuk Budidaya jagung Berkelanjutan. Prosiding Seminar Nasional IX Budidaya Pertanian Olah Tanah Konservasi. Gorongtalo, 6-7 Oktober.

Utomo.M. 2015. Tanpa Olah Tanah, Teknologi Pengelolaan Pertanian Lahan Kering. Penerbit Graha IImu.

Utomo M, F.T.Akbar, dan K.Yunus. 2016. Carbon and Nitrogen Sequestrationsin Long-term No-Tillage Farming System. Workshop on "Sustainabbe Productionof Crops by Appropriate Recycle of Biomass Residues". Universityof Lampung, Bandar Lampung. 